Lima: Centro Cultural «José Pío Aza» y Misioneros Dominicos, 2006, 880 pages

Alonso Ordieres, Rafael (Estudios introductorio, edición y notas de...). La Vida del Pueblo Matsiguenga: Aporte etnográfico de los Misioneros Dominicos al Estudio de la Cultura Matsiguenga (1923-1978). Prólogo de Ricardo Álvarez Lobo (O.P.)

Jaime Regan S.J.

\title{
OpenEdition
}

Journals

Edición electrónica

URL: http://journals.openedition.org/bifea/2946

DOI: $10.4000 /$ bifea.2946

ISSN: 2076-5827

Editor

Institut Français d'Études Andines

Edición impresa

Fecha de publicación: 1 abril 2009

Paginación: 146

ISSN: 0303-7495

Referencia electrónica

Jaime Regan S.J., «Alonso Ordieres, Rafael (Estudios introductorio, edición y notas de...). La Vida del Pueblo Matsiguenga: Aporte etnográfico de los Misioneros Dominicos al Estudio de la Cultura Matsiguenga (1923-1978). Prólogo de Ricardo Álvarez Lobo (O.P.) », Bulletin de I'Institut français d'études andines [En línea], 38 (1) | 2009, Publicado el 01 octubre 2009, consultado el 21 noviembre 2020. URL : http:// journals.openedition.org/bifea/2946; DOI : https://doi.org/10.4000/bifea.2946

Les contenus du Bulletin de l'Institut français d'études andines sont mis à disposition selon les termes de la licence Creative Commons Attribution - Pas d'Utilisation Commerciale - Pas de Modification 4.0 International. 


\section{Rafael Alonso Ordieres (Estudios introductorio, edición y notas de...) La Vida del Pueblo Matsiguenga: Aporte etnográfico de los Misioneros Dominicos al Estudio de la Cultura Matsiguenga (1923-1978). Prólogo de Ricardo Álvarez Lobo, O.P. Lima: Centro Cultural «José Pío Aza» y Misioneros Dominicos, 2006, 880 pps.}

Esta obra es un homenaje a los misioneros dominicos al cumplirse cien años de su presencia en la selva del sur del Perú. Contiene unos 80 estudios etnográficos que tratan el tema de los matsiguengas. Muchos de ellos se publicaron en la revista Misiones Dominicanas del Perú, editada entre 1919 y 1967; el editor ha completado la publicación con artículos del P. Joaquín Barriales escritos entre 1977 y 1979.

Contiene un interesante prólogo del P. Ricardo Álvarez sobre «El Matsiguenga Viajero». EI estudio introductorio abarca los temas de la importancia de la etnografía, testimonios de la comunidad académica científica, breves biografías de los principales autores dominicos y un estudio histórico de sus publicaciones.

El libro se ordena alrededor de diez grandes temas: origen e historia de los matsiguengas; datos demográficos y geográficos; descripción física, psicológica y moral; el idioma matsiguenga; familia y organización social; vida cotidiana y expresiones culturales; actividades económicas y relación con la naturaleza; enfermedad y salud; religiosidad, mitología y creencias; relación con el mundo exterior y los misioneros. Termina con un índice de artículos por orden alfabético de autores, un índice de gráficos, un glosario de términos y un índice general.

Este libro representa un esfuerzo monumental de etnografía a lo largo de muchos años que permite acompañar el desenvolvimiento del pueblo matsiguenga así como las vivencias y sentimientos personales de los misioneros. La presentación ordenada del material hace que sea fácil de manejar tanto para el estudiante principiante como para el investigador experimentado. 